Journal of Clinical Investigation

Vol. 41, No. 8, 1962

\title{
CHANGES IN THE BASAL METABOLIC RATE OF THE MALNOURISHED INFANT AND THEIR RELATION TO BODY COMPOSITION
}

\author{
By R. D. MONTGOMERY * \\ (From the Medical Research Council Tropical Metabolism Research Unit, University College \\ of the West Indies, Jamaica)
}

(Submitted for publication October 24, 1961 ; accepted May 3, 1962)

The measurement of basal metabolic rate in infants by indirect calorimetry was first performed by Rubner and Heubner in an open-circuit apparatus in 1898 (1). A closed-circuit technique was devised by Benedict and Talbot (2) and has since been applied many times (3-5). The normal pattern of changes in basal metabolic rate (BMR) during growth has thus been clearly established.

The effect of malnutrition on this pattern is much less clearly understood. Seven series of studies on marasmic infants have been reported in the past 40 years $(6-12)$. The results indicate that in relation to the subject's actual weight the BMR in marasmus tends to be raised above the normal range, whereas in terms of the expected weight (for age) it tends to be low. The variations in the individual results, however, were very wide. Whereas the normal range for infants weighing up to $13 \mathrm{~kg}$ may be expressed as 45 to 60 calories per $\mathrm{kg}$ per 24 hours (13), the reported values in marasmus have ranged from 48 to 100 .

Almost without exception, these figures were based on single observations, or on the mean of closely repeated observations, on each child at an unstated time during his hospital admission. No series has defined the changes during recovery and re-establishment of growth. The diagnosis of marasmus included a variety of predisposing and complicating conditions, and there have been no comparable measurements in kwashiorkor.

Previous results in infants have run entirely contrary to experience in adult undernutrition, in which a fall in BMR has usually been reported both in terms of surface area and to a lesser extent in terms of body weight (14). It should be noted, however, that Talbot, Dalrymple and Hendry (15) observed a fall in BMR per kilogram in infants after several days' fasting, and Varga (16) found a similar depression in cases of

* Present address: Department of Experimental Medicine, University of Cambridge, England. congenital pyloric stenosis, with a brisk rise during recovery.

In the present study, serial observations were made on Jamaican infants suffering from severe protein malnutrition (17). The purpose of the work was threefold: 1) The oxygen uptake must depend, among other things, on the active tissue mass; its measurement might therefore help in assessing the degree of protein depletion of the body. 2) Protein malnutrition still carries a heavy mortality in hospital, and death is often unexplained. If this were preceded by an irreversible failure of a vital stage in cellular metabolism, it might be reflected in the BMR. 3) Little is known of the factors controlling the rate and pattern of growthrecovery after prolonged deprivation; nor indeed is there any clear understanding of the oxygen demands of an excessive anabolic state, of which these infants in recovery are a unique example.

The protein-depleted infant has an abnormally high content of body water, regardless of the degree of clinical edema, and most if not all of this excess is believed to be in the extracellular phase (18-20). As a basis of reference, therefore, the body solid mass, although it includes fat and minerals, may be preferable to the body weight. For this reason, concomitant studies were made of total body water, and the metabolic rate was considered in terms of body solid mass.

\section{CLINICAL SUBJECTS}

Thirty-six malnourished infants were studied. Their ages on admission ranged from 4 to 30 months, and the body weight, after loss of clinical edema, ranged from 30 to 72 per cent of the normal weight for their age by American standards (21). The clinical picture ranged from frank marasmus, in which the baby might be mentally alert and hungry but showed extreme loss of fat and muscle and stunting of growth, to the full picture of kwashiorkor, with profound weakness, mental apathy, irritability and anorexia, gross edema, enlarged fatty liver, mucocutaneous ulceration, and the characteristic pigmentary changes of skin and hair (22). The majority fell 


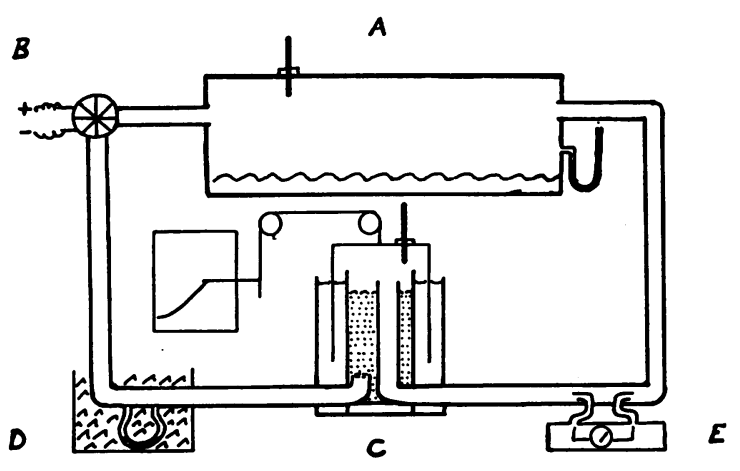

Fig. 1. Diagram of BMR apparatus in the PRESENT study. $A=$ respiration chamber. $B=$ fan-type air pump. $\mathrm{C}=$ Kendrick respirometer and 60 -minute recording drum. $\mathrm{D}=$ ice bath. $\mathrm{E}=\mathrm{CO}_{2}$ Katharometer.

into an intermediate category of marasmic kwashiorkor $(23,24)$, with severe wasting accompanied by apathy, mild or moderate edema, hepatomegaly, and variable skin and hair changes. The history of malnutrition appeared to date from the cessation of breast feeding, development usually being normal during the first few months of life.

In all cases protein malnutrition appeared to be the primary condition, other features such as gastroenteritis or sepsis being of less importance. None of the infants was pyrexial at the time of study. Two of the infants died within 5 days of admission.

\section{METHODS}

Oxygen consumption. Indirect calorimetry was performed in a closed circuit consisting of a metal respiration chamber connected by 1 -inch Perspex tubing to a fantype air pump and a modified British Benedict (Kendrick) respirometer (Figure 1). The respiration chamber, of 52-L volume, had a reinforced Perspex lid sealed by a vaseline-coated rubber ring and quick-release clamps. The pump was a Hoover "Dustette" type fitted to a variable resistance and totally enclosed in a copper cylinder with 1-inch outlets. 1 At the start of a test, some 5 $\mathrm{L}$ of oxygen was run into the system. Absorption of carbon dioxide was by "Calsoda" (Kendrick), and oxygen uptake was measured volumetrically by the respirometer, which was fitted to a 60-minute recording drum. Cooling was maintained by passing the tubing through a bath of chipped ice, condensed water being collected in a rubber U-tube. An air sample was continuously monitored for carbon dioxide content by passage through a Cambridge Katharometer.

The infant was lightly sedated with oral paraldehyde in the postabsorptive state ( 3 to 6 hours after feeding) and placed in the chamber on foam rubber and diapers. Soon after admission, ill babies did not require sedation but remained asleep or apathetically awake throughout the test. The others all fell asleep before or soon after the start of the test and seldom awoke before the end. Restless periods rarely occurred during the test and were apparent on the tracing of the recording drum. The experiment was run for 45 to 50 minutes, and readings were based on the record of the last 20 minutes. Control tests of the apparatus without an infant were made every few days to record the baseline, which was always horizontal after 30 minutes' running. Duplicate tests on successive days were made in the case of 5 infants, and the results showed a variation in oxygen uptake of 0 to 4 per cent.

Excess air space in the chamber was filled to maintain the circulating air volume at 44 to $46 \mathrm{~L}$. The temperature rise during the test period ranged from 0 to $0.8^{\circ} \mathrm{C}$. An appropriate correction was made for the change in air volume. Throughout the 18 months of these experiments the room temperature ranged only from $26.5^{\circ}$ to $30^{\circ} \mathrm{C}$ $\left(80^{\circ}\right.$ to $\left.86^{\circ} \mathrm{F}\right)$ and the atmospheric pressure from 745 to $749 \mathrm{~mm} \mathrm{Hg}$. A constant factor was therefore used for correction of volumes to $0^{\circ} \mathrm{C}$ and $760 \mathrm{~mm} \mathrm{Hg}$.

The temperature in the chamber during the test period averaged $30^{\circ} \mathrm{C}\left(86^{\circ} \mathrm{F}\right)$, which may be considered to be in the zone of thermal neutrality for the infant. Rectal temperatures in 6 cases were found to be normal before and after the test.

The figures for oxygen consumption were conventionally converted to terms of caloric output by assuming a respiratory quotient of 0.86 and a calorific value for oxygen of 4.825 calories per $L(2,5)$. Except where otherwise defined, the term $B M R$ in this text refers to the value of calories per $\mathrm{kg}$ per 24 hours.

BMR was also considered in terms of weight-in-kilograms $^{3}$ as an approximate index of surface area, and in terms of Karlberg's "capacitance" surface area (5) calculated from his height-weight nomogram, which has proved to be a more precise basis for expressing the normal BMR per square meter.

Controls. Seven Jamaican infants were tested as controls. Four of these had been patients with malnutrition at least 4 months previously. At the time of testing they were all growing satisfactorily on an adequate home diet and were representative of healthy Jamaican infants of poor parentage. They all had an appreciable weight deficit by North American standards (Table I), but it has been suggested that such "normal" standards are set some 15 per cent too high for breast-fed infants in underdeveloped countries (25).

Body water. Total body water was estimated by the method of Bradley, Davidsson, MacIntyre and Rapoport (26) as modified by Smith (20). Tritiated water was given by intramuscular injection, and the radioactivity in successive urine samples was measured in a stream of helium in a sensitive gas-flow counter.

Eighteen estimations were made on nine infants whose BMR was studied during the same period, estimations being made at the time when body weight was minimal and again during the stage of recovery.

1 I am grateful for the invaluable aid of Dr. B. M. Wright and the technical staff of the National Institute for Medical Research, Mill Hill, London, England, in the construction of the apparatus. 


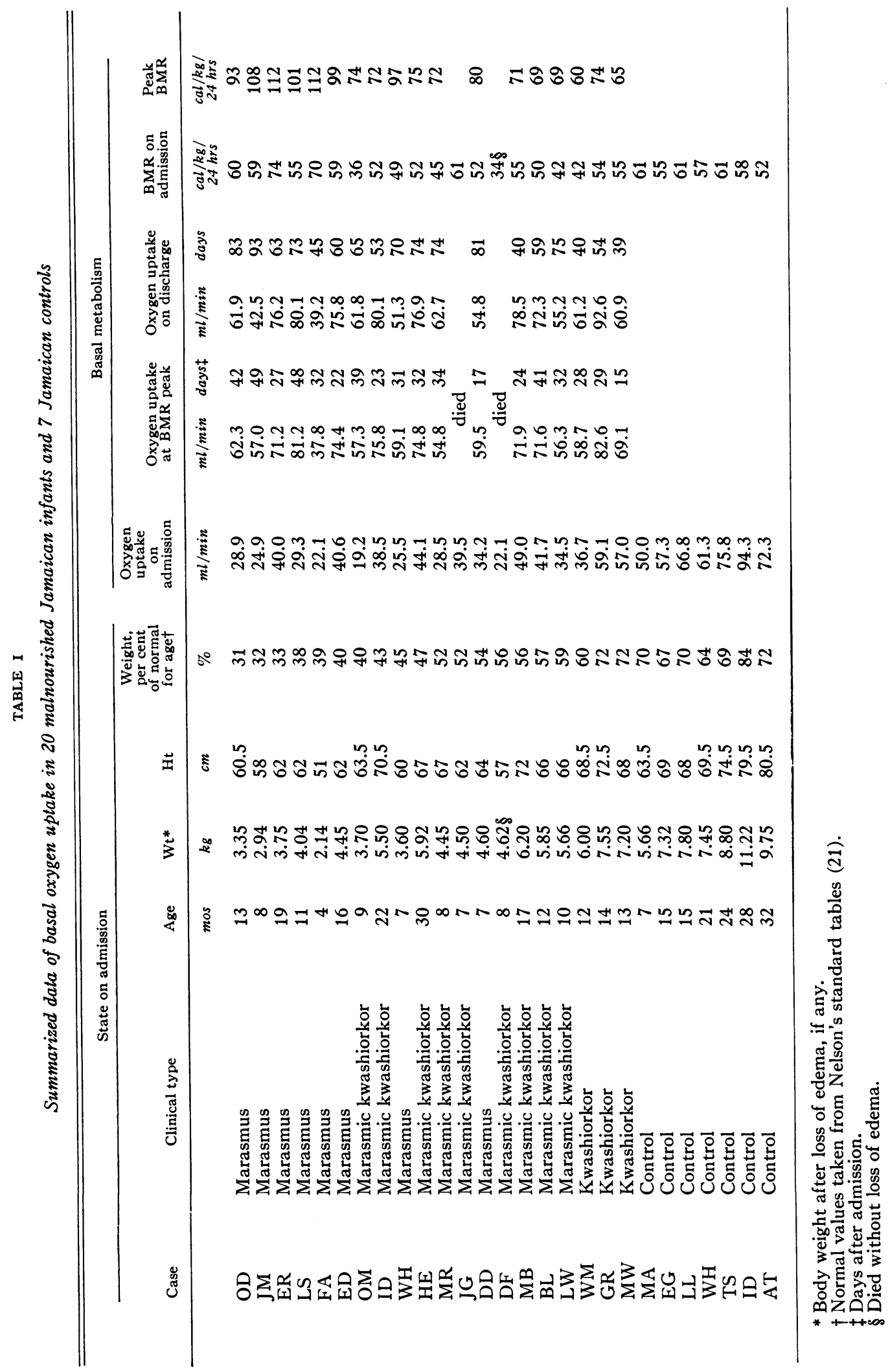




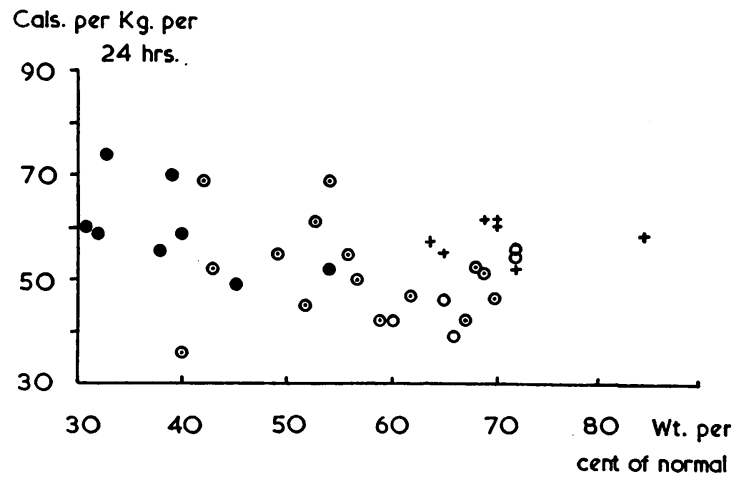

Fig. 2. Initial BMR in 28 malnourished Jamaican INFANTS AND IN 7 JAMAICAN controls. The abscissa represents the body weight as a percentage of the normal weight for age (21). In edematous cases the initial weight was taken to be the minimum weight after loss of edema. $-=$ marasmus ; $O=$ kwashiorkor $; \odot=$ marasmic kwashiorkor; $+=$ controls.

\section{RESULTS}

$B M R$ in controls. The figures of oxygen consumption in Jamaican controls are given at the bottom of Table I. The BMR range of 52 to 61 calories per $\mathrm{kg}$ per 24 hours is similar to that of Talbot (27) but slightly higher than that of Karlberg (5). Possible factors tending to increase the BMR of these subjects are discussed below.

Initial BMR in malnutrition. Initial BMR figures in the three clinical groups are shown in Figure 2 and Table I and are summarized as percentages of normal in Table II. In terms of edema-free body weight, the BMR was variable

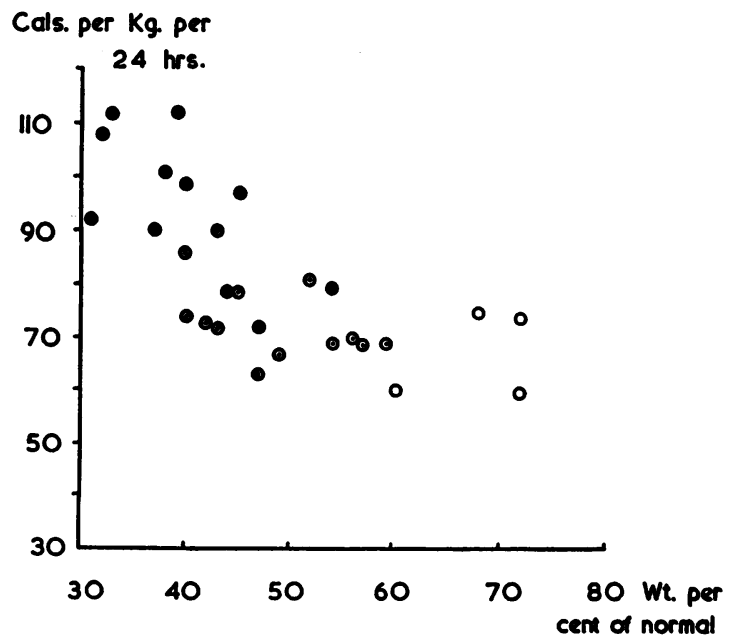

Fig. 3. Observed PeAK BMR dURINg Rehabilitation. Abscissa and symbols as in Figure 2. about a normal mean, being higher in the marasmic group and lower in frank kwashiorkor. In terms of "capacitance" surface area, metabolism was subnormal in 22 of 28 cases, when related to Karlberg's 95 per cent confidence intervals, but the variation was equally great, high figures being found in several marasmic cases. Expression of metabolism in terms of weight $^{\frac{3}{3}}$ gave results closely comparable to those in terms of capacitance surface area.

$B M R$ changes in recovery. In each case, whatever the initial value, the BMR invariably rose during recovery, and this rise sometimes preceded the weight gain. Peak values ranging from 60 to 112 calories per $\mathrm{kg}$ per 24 hours were reached in 2

TABLE II

Initial BMR in malnutrition, in terms of body weight and "capacitance" surface area, expressed as percentages of normal *

\begin{tabular}{|c|c|c|c|}
\hline Clinical group & $\begin{array}{l}\text { Weight, } \\
\text { per cent } \\
\text { of theoret- } \\
\text { ical weight } \\
\text { for age }\end{array}$ & $\begin{array}{l}\text { BMR (per } \\
\text { kg), per } \\
\text { cent of } \\
\text { normal }\end{array}$ & $\begin{array}{c}\text { BMR (per } \\
\text { ma), per } \\
\text { cent of } \\
\text { normal }\end{array}$ \\
\hline Marasmus (11 cases) & $\begin{array}{c}\% \\
40 \\
(31-54)\end{array}$ & $\begin{array}{c}\% \\
113 \\
(92-140)\end{array}$ & $\begin{array}{c}\% \\
97 \\
(75-138)\end{array}$ \\
\hline $\begin{array}{l}\text { Marasmic kwashiorkor } \\
\text { (20 cases) }\end{array}$ & $\begin{array}{c}54 \\
(40-70)\end{array}$ & $\begin{array}{c}96 \\
(64-130)\end{array}$ & $\begin{array}{c}85 \\
(56-113)\end{array}$ \\
\hline Kwashiorkor (5 cases) & $\begin{array}{c}67 \\
(60-72)\end{array}$ & $\begin{array}{c}89 \\
(74-104)\end{array}$ & $\begin{array}{c}83 \\
(76-103)\end{array}$ \\
\hline
\end{tabular}

* In edematous cases initial weight is taken as the minimum after loss of edema. Normal BMR is taken as $53 \mathrm{cals} / \mathrm{kg} / 24$ hours (13). The figures in terms of capacitance surface area and their relation to normal are taken from Karlberg's height-weight nomogram (5). Theo-
retical weights for age are taken from American standard tables (21).

to 6 weeks (Figure 3), after which the levels declined toward the normal. This remarkable change of respiratory behavior in the individual in the course of a few weeks helps to explain wide variations between the isolated observations of earlier workers.

Relation of BMR to body weight. Marasmic infants not only had higher initial levels of BMR than cases of kwashiorkor, but they showed a more dramatic rise to peak levels during recovery (Figures 3-5). The marasmic group were the most wasted in relation to the normal for age, and it can be seen from Figure 3 that the more emaciated the child, the higher was the BMR peak during recovery. This correlation was more apparent with respect to the weight deficit in relation to age than with the deficit in relation to height. 
Platean of oxygen uptake in recovery. The changes in total basal oxygen uptake in recovery are summarized in Table I. The peak level of BMR represents the beginning of a plateau level of oxygen consumption which is maintained regardless of the further acute changes in the child's body size (Figure 6). Once this plateau is reached the BMR per kilogram falls as weight gain proceeds. Over a period of many months, the plateau shows a gradual rise with increasing age (Figure 7).

Oxygen uptake at the plateau is of the same order as that of Jamaican controls of the same age.

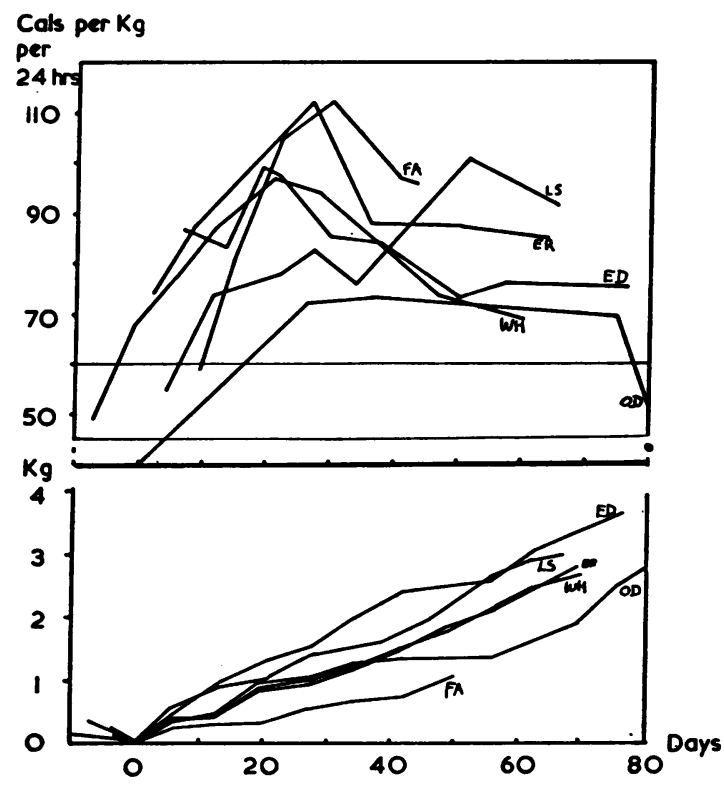

Fig. 4. Changes IN BMR during Recovery in 6 MARASMIC CASES. The changes in body weight are shown in the lower panel. Day $0=$ day of minimum weight.

It is constantly between 68 and 98 per cent of the uptake of a normal American child of the same age, based on a normal BMR of 53 calories per $\mathrm{kg}$ per 24 hours (13). As can be seen from Table III, there is no such correlation with the oxygen uptake of normal children of the same height or the same surface area.

Relation of oxygen uptake to the caloric value of the diet. In the treatment of marasmic infants a very high caloric intake may be required to achieve weight gain. The present data (Table IV) indicate that the more emaciated the child, the greater this minimal intake tends to be, and

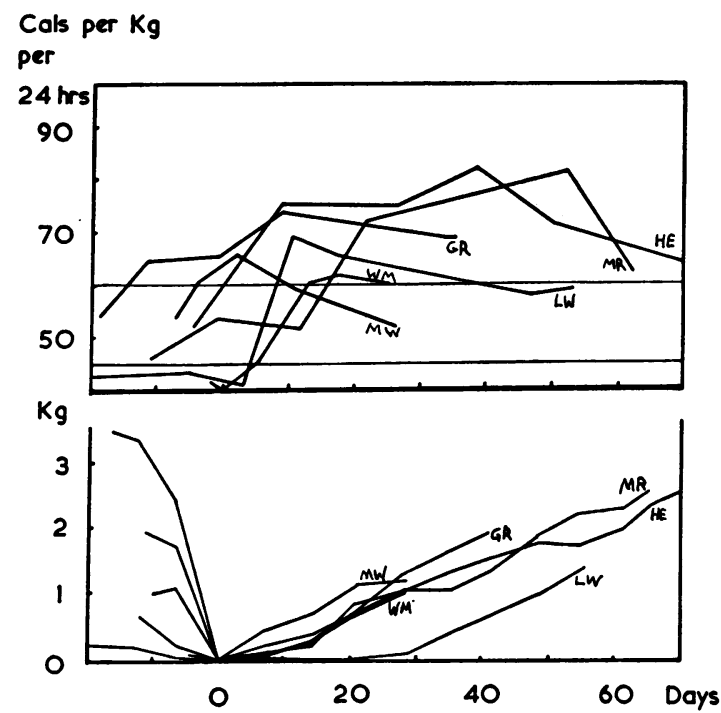

Fig. 5. Changes IN BMR DURING RECOVERY IN 6 CASES OF KWASHIORKOR. The changes in body weight are shown in the lower panel. Day $0=$ day of minimum weight.

suggest that this depends on the changes in BMR. Thus the primary effect of increased caloric intake is a rise in BMR, but it is only when the caloric intake exceeds the basal caloric consumption by 60 to 85 calories per $\mathrm{kg}$ that growth results.

In some cases a high calorie intake was rapidly achieved (FA, OM, ID, BW, RB; Table IV) and weight gain commenced before the $\mathrm{BMR}$ had

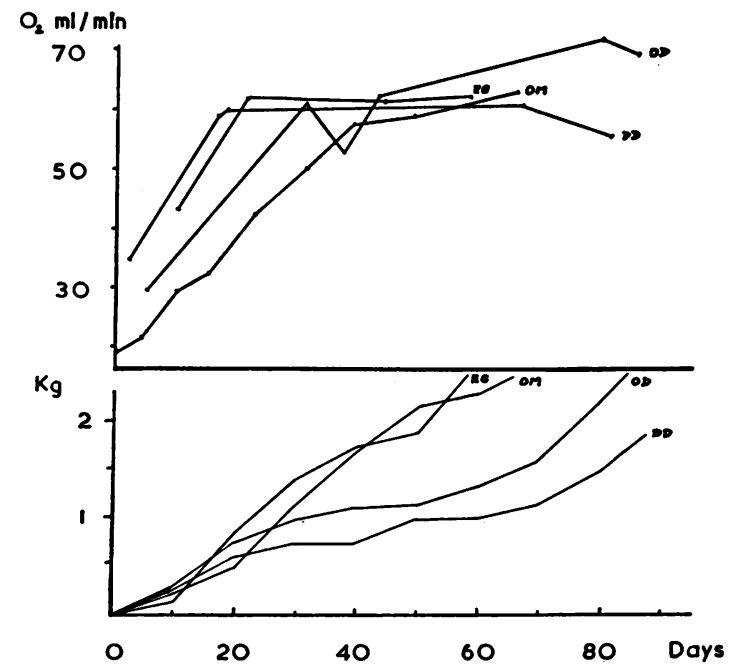

Fig. 6. Changes in total basal OXYGEN CONSUMPTION IN 4 TYPICAL CASES IN RECOVERY, SHOWING THE "PLATEAU" LEVEL. The changes in body weight are shown in the lower panel. 


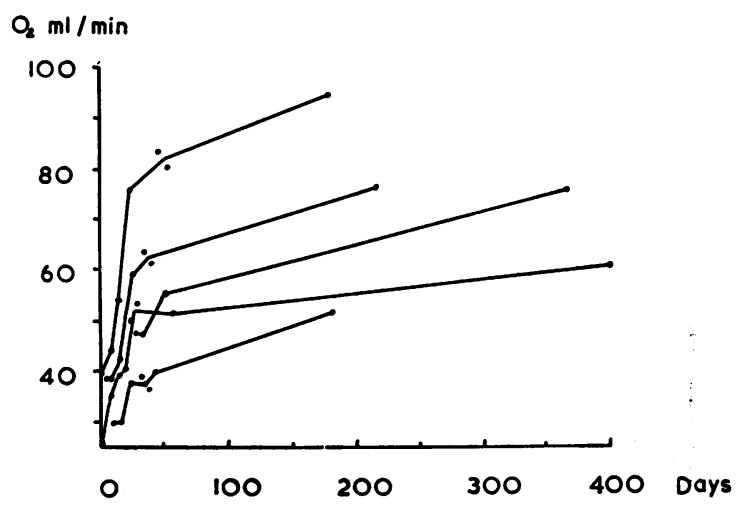

Fig. 7. LONG-TERM STUDIES OF BASAL OXYGEN CONSUMPTION IN RECOVERY IN 5 FURTHER CASES, SHOWING A SLOW RISE IN THE PLATEAU LEVEL.

reached its peak. More often the intake could only slowly be built up, and as the BMR rose a correspondingly higher intake was needed for growth. In cases FA and RB, the BMR "overtook" the intake, and weight gain temporarily ceased.

These interpretations presuppose that on a milk diet calories rather than protein tend to be the limiting factor in growth (28).

TABLE III

"Plateau" level of oxygen uptake in recovery: percentage of normal on the basis of weight, height, capacitance surface area, and age *

\begin{tabular}{|c|c|c|c|c|}
\hline \multirow[b]{2}{*}{ Case } & \multicolumn{4}{|c|}{$\begin{array}{l}\text { Uptake as a percentage of the normal } \\
\text { in a child of : }\end{array}$} \\
\hline & $\begin{array}{c}\text { Same } \\
\text { weight }\end{array}$ & $\begin{array}{l}\text { Same } \\
\text { height }\end{array}$ & $\begin{array}{c}\text { Same } \\
\text { capacitance } \\
\text { surface } \\
\text { area }\end{array}$ & $\begin{array}{c}\text { Same } \\
\text { age }\end{array}$ \\
\hline $\begin{array}{l}\text { FA } \\
\text { ER } \\
\text { JM } \\
\text { LS } \\
\text { ED } \\
\text { WH } \\
\text { OD } \\
\text { LC } \\
\text { EG } \\
\text { DS } \\
\text { DG } \\
\text { RB } \\
\text { OM } \\
\text { CR } \\
\text { MR } \\
\text { ID } \\
\text { MB } \\
\text { BL } \\
\text { LW } \\
\text { GF } \\
\text { GR } \\
\text { BW } \\
\text { DB } \\
\text { MW } \\
\text { WM }\end{array}$ & $\begin{array}{c}\% \\
211 \\
211 \\
203 \\
190 \\
186 \\
182 \\
173 \\
170 \\
161 \\
150 \\
148 \\
141 \\
139 \\
137 \\
135 \\
133 \\
132 \\
132 \\
130 \\
130 \\
120 \\
118 \\
115 \\
113 \\
113\end{array}$ & $\begin{array}{r}\% \\
157 \\
141 \\
141 \\
133 \\
148 \\
128 \\
132 \\
103 \\
132 \\
109 \\
110 \\
79 \\
102 \\
105 \\
88 \\
109 \\
102 \\
105 \\
89 \\
85 \\
94 \\
107 \\
84 \\
102 \\
94\end{array}$ & $\begin{array}{c}\% \\
157 \\
182 \\
167 \\
182 \\
171 \\
157 \\
154 \\
160 \\
150 \\
133 \\
135 \\
130 \\
126 \\
128 \\
115 \\
124 \\
120 \\
128 \\
119 \\
130 \\
111 \\
118 \\
105 \\
109 \\
11\end{array}$ & $\begin{array}{l}\% \\
81 \\
77 \\
79 \\
98 \\
86 \\
88 \\
71 \\
73 \\
75 \\
88 \\
88 \\
75 \\
79 \\
79 \\
94 \\
79 \\
90 \\
86 \\
73 \\
70 \\
94 \\
68 \\
85 \\
85 \\
80\end{array}$ \\
\hline Range & $113-211$ & $79-157$ & $105-182$ & $68-98$ \\
\hline
\end{tabular}

* Normal values are based on standard tables (21) and a BMR value of 53 calories per $\mathrm{kg}$ per 24 hours (13).
Relation of oxygen uptake to dietary protein. At the time when a plateau of oxygen uptake was reached, the infants were usually receiving a fullstrength milk mixture fortified by peanut oil, giving a protein intake of the order of $4 \mathrm{~g}$ per $\mathrm{kg}$ per day. In some cases supplements of cereals, vegetables, and bread had already begun.

Tests were made of the effect on oxygen uptake of altering the diet to : $a$ ) a low-calorie protein-free diet of 5 per cent dextrose in $0.333 \mathrm{~N}$ saline, or $b$ ) an isocaloric low protein diet in which starch was substituted for skim milk. Four infants were tested on $a$ and seven on $b$. The change was made at

TABLE IV

Correlation between the observed minimal caloric requirement for growth and the $B M R$ at the same time

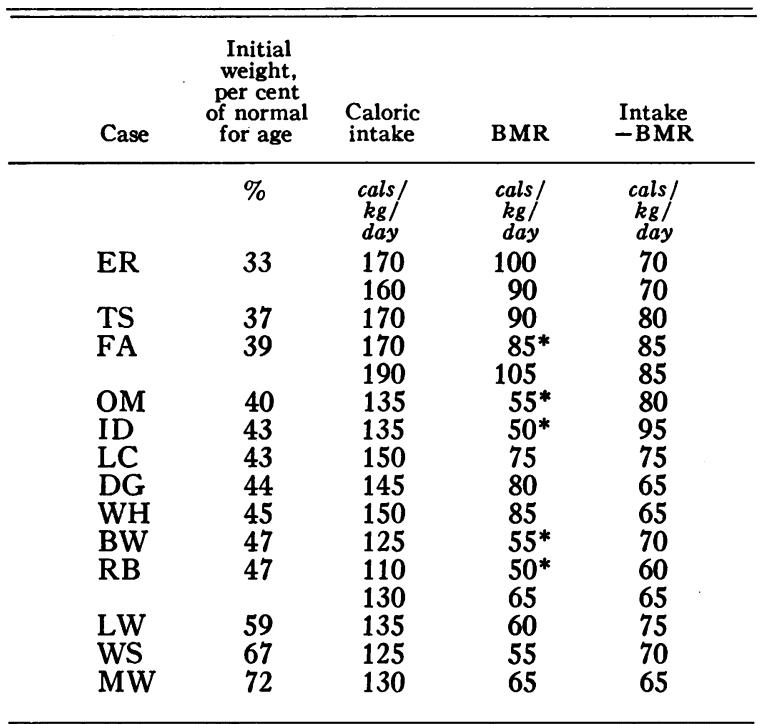

* Weight gain commenced before the BMR peak (see text).

a time when the child was gaining weight steadily and had reached a steady plateau level of oxygen uptake. The starch diet was known from previous experience to be inadequate for growth, although the child often maintained weight, as was the case in this series.

In all cases on dextrose-saline, the oxygen uptake fell abruptly and severely, but only after a latent interval of 48 hours. On the starch diet, the same latent interval was observed, followed in three cases by a more gradual fall; in the remainder, no significant fall occurred during test periods of up to 11 days. The mean daily protein intake on the starch diet was $0.87 \mathrm{~g}$ per $\mathrm{kg}$ in the 
TABLE V

Total body water and the metabolic activity of body solids in malnourished infants

\begin{tabular}{|c|c|c|c|c|c|c|}
\hline \multirow[t]{2}{*}{ Case } & \multirow[t]{2}{*}{ Clinical diagnosis } & \multirow{2}{*}{$\begin{array}{c}\begin{array}{c}\text { Total body } \\
\text { water, per } \\
\text { cent of } \\
\text { body weight } \\
\text { (normal } \\
55-65)\end{array} \\
\%\end{array}$} & \multirow{2}{*}{ 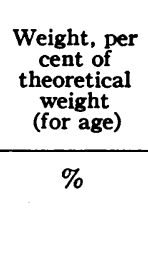 } & \multirow{2}{*}{$\begin{array}{c}\text { Body solid } \\
\text { mass, per } \\
\text { cent of } \\
\text { theoretical } \\
\text { solid mass } \\
\text { (for age) }\end{array}$} & \multicolumn{2}{|c|}{$\begin{array}{c}\text { BMR within a } \\
\text { week of admission }\end{array}$} \\
\hline & & & & & $\begin{array}{c}\text { cals } / \mathrm{kg} \\
\text { body wt/ } \\
24 \mathrm{hrs} \\
\text { (Normal } \\
45-60)\end{array}$ & $\begin{array}{c}\text { cals } / \text { kg } \\
\text { body solids / } \\
24 \text { hrs } \\
\text { (Normal } \\
100-170)\end{array}$ \\
\hline $\begin{array}{l}\text { JM } \\
\text { WH } \\
\text { MR } \\
\text { WS } \\
\text { LW } \\
\text { GF } \\
\text { OM } \\
\text { GR } \\
\text { MW }\end{array}$ & $\begin{array}{l}\text { Marasmus } \\
\text { Marasmus } \\
\text { Marasmic kwashiorkor } \\
\text { Marasmic kwashiorkor } \\
\text { Marasmic kwashiorkor } \\
\text { Marasmic kwashiorkor } \\
\text { Marasmic kwashiorkor } \\
\text { Kwashiorkor } \\
\text { Kwashiorkor }\end{array}$ & $\begin{array}{l}75 \\
71 \\
80 \\
75 \\
73 \\
63 \\
73 \\
61 \\
60\end{array}$ & $\begin{array}{l}32 \\
45 \\
52 \\
67 \\
59 \\
54 \\
40 \\
72 \\
72\end{array}$ & $\begin{array}{l}20 \\
33 \\
26 \\
42 \\
40 \\
50 \\
27 \\
71 \\
72\end{array}$ & $\begin{array}{l}59 \\
49 \\
45 \\
42 \\
42 \\
69 \\
36 \\
54 \\
55\end{array}$ & $\begin{array}{l}236 \\
163 \\
225 \\
168 \\
155 \\
186 \\
133 \\
139 \\
138\end{array}$ \\
\hline
\end{tabular}

cases in which the oxygen consumption fell, and $1.10 \mathrm{~g}$ per $\mathrm{kg}$ in the remainder. These findings suggest that a protein intake of about $1 \mathrm{~g}$ per $\mathrm{kg}$ is critical in maintaining the oxygen plateau during recovery.

Relation of oxygen uptake to body solids. The tendency to a high body water content in protein malnutrition was confirmed (Table V). In three grave cases, the body solid mass including fat was initially less than 30 per cent of the normal for age, whereas the body weight was 32 to 52 per cent of normal.

If the body solid content of normal infants is taken as 35 to 45 per cent $(19,29)$, the normal BMR range of 45 to 60 calories per $\mathrm{kg}$ body weight per day represents 100 to 170 calories per $\mathrm{kg}$ body solids. The range in nine malnourished infants studied soon after admission was 134 to 236 calories per $\mathrm{kg}$ body solids per day (mean 171) (Table V).

The deficit of body solids correlated with the degree of their respiratory hyperactivity at the peak of recovery (Figure 8 ), in the same way as did the deficit in body weight with BMR (Figure $3)$.

\section{DISCUSSION}

In the untreated case the oxygen consumption, expressed either in terms of body weight or of body solid mass, tends to be depressed in frank kwashiorkor but not in marasmus.

These parameters however are fallacious for two reasons: 1) a reduction in the proportion of fat in the body solid mass will cause apparent increase in the metabolic activity of the remainder; and 2) the body solid mass is not only reduced in amount compared with a normal child of the same age (Table V); it is also altered as regards the proportions contributed by different organs and tissues.

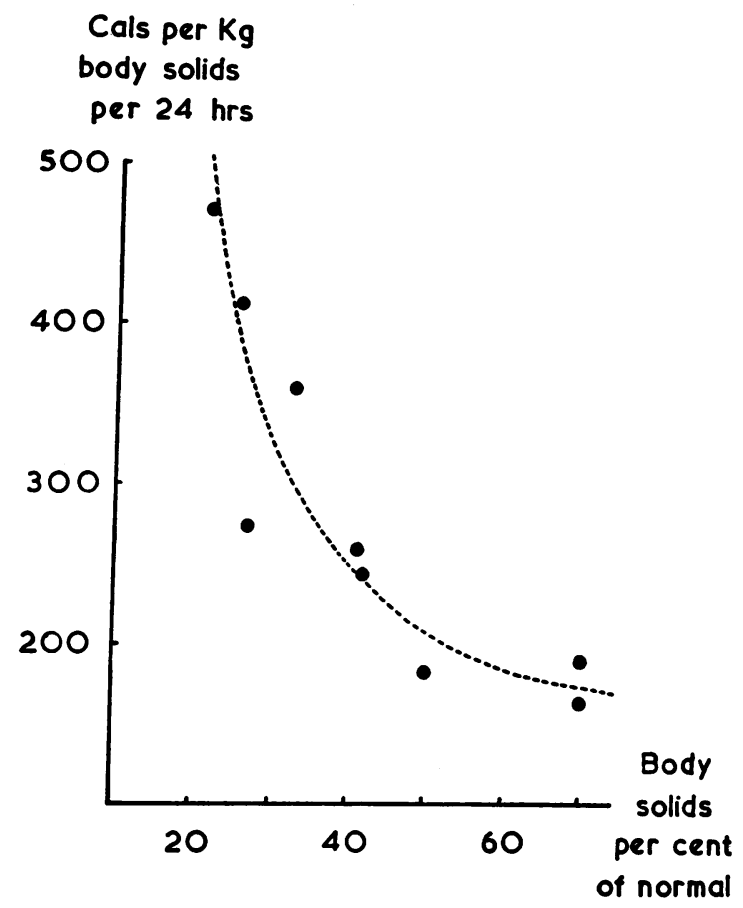

Fig. 8. The Relation OF BODY SOLID RESPIRATORY ACTIVITY AT THE PEAK OF RECOVERY TO THE DEFICIT IN BODY SOLID MASS. Body solids are expressed as a percentage of the normal for age. The highest activity occurs in the most depleted cases. 
Fat content of body solids. In the normal man or animal, an approximate calculation of body fat can be made from the body weight and the body solid mass by assuming a constant figure of 28 per cent for the proportion of lean body solid mass (LBS) to lean body weight $(30-32)$. The figures for body water show that this relation ceases to be valid in malnutrition. Nor is a normal ratio maintained of LBS to total body weight (about 22 per cent), for the body solids may be 20 per cent or less of the body weight in edema-free cases (20), in some of whom significant amounts of fat are known to be present.

Although we have no true measure of the fat content of the body solids, clinical observation agrees with the trends of the data in Table V. The lowest figures for respiratory activity of body solids were found in cases in whom body fat was most apparent, and the highest figures were in marasmic infants whose fat content was minimal. The latter figures fall within or below the normal range in terms of LBS (205 to 275 calories per $\mathrm{kg}$ LBS per 24 hours).

In short, whereas the oxygen uptake in terms of body solid mass varies widely about a high normal mean, the uptake of the lean solids appears to be more constant in or below the normal range. This is in keeping with the finding of lowered metabolism in terms of surface area, since surface area is roughly proportional to LBS (33).

Pattern of body solids. In the malnourished growing animal, the "body pattern" is altered at several different levels : 1) The growth of different organs is retarded to different degrees-brain, heart, and kidney being less retarded or depleted than liver, pancreas, and muscle (34-37). 2) A rough division may be made into proteins that are relatively fixed, mainly extracellular, such as collagen, and those that are more mobile, such as the cytoplasmic proteins of parenchymatous cells (38). There is evidence that some of the fixed protein is much less reduced in amount than are the mobile proteins $(36,39)$. 3) At cellular level, the composition of the cell is altered by shrinkage of the cytoplasm in relation to the nucleus $(40,41)$.

To consider the way in which these alterations in pattern may affect the oxygen uptake, the brain may be taken as a striking example for two reasons: 1 ) It is probable that only minor changes in its metabolic rate are compatible with conscious life; and 2) of all organs, the absolute weight of the brain is least affected by malnutrition.

In the normal infant at 1 year, the brain weight is some 9 per cent of body weight, that is, a brain of $900 \mathrm{~g}$ may be found in a $10 \mathrm{~kg}$ child. In a series of malnourished infants, the brain has been found to weigh up to 18 per cent of body weight at 1 year, e.g., $700 \mathrm{~g}$ in a $4 \mathrm{~kg}$ child (42).

No figures are available for the oxygen uptake of the brain in young infants, but for the purposes of calculation two figures may be used:1) the rate in normal adults $(33 \mathrm{ml}$ per $\mathrm{kg}$ per minute $=$ approximately 200 calories per $\mathrm{kg}$ per day); and 2) the rate found in adults in coma, which may be considered to approach the lower limit compatible with life $(20 \mathrm{ml}$ per $\mathrm{kg}$ per minute $=$ approximately 150 calories per $\mathrm{kg}$ per day) (43). These figures may exaggerate the true values in adults by at least 30 per cent owing to systematic errors (44). On the other hand, a brain oxygen uptake as high as $\mathbf{5 0}$

TABLE VI

Derived metabolic data from observed brain weight in malnutrition, suggesting that there is over-all depression of metabolism of the lean body mass (LBM)

\begin{tabular}{|c|c|c|c|c|c|c|c|c|c|c|c|}
\hline & $\begin{array}{c}\text { Body } \\
\text { wt }\end{array}$ & $\begin{array}{l}\text { Assumed } \\
\text { fat } \\
\text { content } \\
\text { of body }\end{array}$ & LBM & BMR* & $\begin{array}{c}\text { E } \\
\begin{array}{c}\text { Total } \\
\text { metab- } \\
\text { olism } \\
\text { of body } \\
(\mathrm{D} \times \mathbf{A})\end{array}\end{array}$ & $\underset{w t}{\text { Brain }}$ & $\begin{array}{l}\text { Meta- } \\
\text { bolict } \\
\text { rate of } \\
\text { brain }\end{array}$ & $\begin{array}{l}\text { Total } \\
\text { metab- } \\
\text { olism } \\
\text { of brain } \\
(\mathbf{G} \times \mathbf{F})\end{array}$ & $\begin{array}{c}\text { I } \\
\text { Total } \\
\text { metab- } \\
\text { olism } \\
\text { of rest of } \\
\text { LBM } \\
\text { (E-H) }\end{array}$ & $\begin{array}{l}\text { Wt of } \\
\text { rest of } \\
\text { LBM } \\
(\mathrm{C}-\mathrm{F})\end{array}$ & $\begin{array}{c}\text { K } \\
\text { Meta- } \\
\text { bolic } \\
\text { rate of } \\
\text { LBM } \\
\text { other } \\
\text { than } \\
\text { brain } \\
\text { (I/J }\end{array}$ \\
\hline & kg & $\%$ & kg & $\begin{array}{c}\text { cals/ } \\
\text { kg } \\
\text { day }\end{array}$ & $\begin{array}{c}\text { cals/ } \\
\text { day }\end{array}$ & kg & $\begin{array}{c}\text { cals/ } \\
\text { kg/ } \\
\text { day }\end{array}$ & $\begin{array}{c}\text { cals/ } \\
\text { day }\end{array}$ & $\begin{array}{c}\text { cals / } \\
\text { day }\end{array}$ & kg & $\begin{array}{c}\text { cals/ } \\
\text { kg } \\
\text { day }\end{array}$ \\
\hline \multirow{2}{*}{$\begin{array}{l}\text { Normal } \\
\text { Malnutrition, initial } \\
\text { Malnutrition at } \\
\text { oxygen plateau }\end{array}$} & $\begin{array}{r}10 \\
4\end{array}$ & $\begin{array}{r}20 \\
5\end{array}$ & $\begin{array}{l}8 \\
3.8\end{array}$ & $\begin{array}{l}\mathbf{5 0} \\
\mathbf{5 0}\end{array}$ & $\begin{array}{l}500 \\
200\end{array}$ & $\begin{array}{l}0.9 \\
0.7\end{array}$ & $\begin{array}{l}200 \\
150\end{array}$ & $\begin{array}{l}180 \\
105\end{array}$ & $\begin{array}{r}320 \\
95\end{array}$ & $\begin{array}{l}7.1 \\
3.1\end{array}$ & $\begin{array}{l}45 \\
31\end{array}$ \\
\hline & 5 & 8 & 4.6 & 80 & 400 & 0.7 & 200 & 140 & 260 & 3.9 & 67 \\
\hline
\end{tabular}

* See Table I.

† For assumptions"see text. 
$\mathrm{ml}$ per $\mathrm{kg}$ per minute has been reported in normal 5 year old children (45).

Table VI has been constructed with the adult figures. It leads to a conclusion that at first sight seems paradoxical-that although the over-all metabolic rate may be normal, the metabolism of the individual organs is depressed. The reason for this, of course, is the high proportion of the malnourished body taken up by organs that normally have a high rate of activity. Although in the lean body mass other than brain there is probably an increased proportion of inactive protein such as collagen, it is difficult to believe that this alone could account for the depression of metabolic rate suggested by the calculation, which had already presupposed a depression of brain metabolism. The depression could, however, be partly accounted for by the excess of water.

$B M R$ in marasmus. It has been noted that some cases of marasmus showed a high initial BMR both in terms of body weight and surface area. These cases were the most wasted of the whole series and presumably, therefore, had the highest proportion of relatively active brain. It has also been shown that a diet inadequate in calories but "marginal" in protein may result in a sustained increase in BMR without detectable weight gain. That this might have been the initial state of these few infants is suggested by the fact that they were mentally alert and physically active, in contrast to the profoundly mentally apathetic and irritable majority.

Oxygen plateau in recovery. The higher proportion of brain in the body of the Jamaican controls as compared with their heavier American counterparts may account for the fact that their BMR lies in the upper range of "normal." Similarly, the mere restoration of normal activity to the most active organs in the malnourished infant may partly explain the great rise in oxygen uptake during recovery. In addition, there is the high oxygen demand of accelerated anabolism in muscle and in the other tissues which have been the most seriously depleted.

What factors determine the peak level of metabolism? Although it might be anticipated that this acceleration of growth calls for balanced hyperactivity of the endocrine system, radioiodine studies suggest that the thyroid gland plays no significant part in initiating the oxygen changes (42).

The close relation of the level of the oxygen plateau to age is surprising. One possible explanation has already been offered: the recovery of normal activity in those organs whose mass has fallen off least in relation to the normal for age. Another factor arises from consideration of metabolism at cellular level. Respiration in the cell is primarily a function of the mitochondria (46), and it may well be that in an adult cell made smaller by protein depletion the potential respiratory activity of the mitochondria is relatively less affected. Thus when optimal conditions are restored, the "metabolic potential" of a body of recovering cells may be related to the cell number rather than to the total cell mass.

In this context, Gray and Deluca (47) found that the respiratory activity of the isolated diaphragm in malnourished rats was increased in terms of tissue mass but was normal in terms of desoxyribonucleic acid, i.e., per "cell unit."

In the child, the picture is complicated by cell growth. There is evidence that in the young rat liver, with complete interruption of body growth by undernutrition, the liver size and total protein content remain constant, but the number of nuclei increases slowly (39). A roughly similar relationship has been found between the mass and sarcolemmal nuclear count of sartorius muscle in malnourished infants (42). Thus in long-standing malnutrition, the increased number of cells per unit of tissue mass may influence the limit of increased oxygen uptake during recovery.

\section{SUMMARY}

1. The basal metabolic rate (BMR) was studied by a closed-circuit system in 36 infants suffering from and recovering from severe protein malnutrition. In nine cases, concomitant studies were made of total body water by tritium dilution.

2. In most cases, the initial oxygen consumption tended to be subnormal in relation to calculated surface area, but was approximately normal in terms of body weight and of body solid mass. However, owing to an abnormal preponderance of the most metabolically active organs, notably the brain, this finding suggests a true depression of respiratory activity in the individual organs. In 
a few marasmic cases, the BMR was initially increased both in terms of body weight and surface area.

3. Serial tests showed a dramatic rise in total oxygen consumption, often more than twofold, during the early weeks of recovery. This rise was followed by a plateau level which was maintained regardless of variable gains in weight. Total oxygen consumption at this plateau level approached the normal for a healthy child of the same age.

4. Body weight did not increase unless the caloric intake consistently exceeded the BMR by 60 to 85 calories per $\mathrm{kg}$ per day. The greater the weight deficit, the higher was the BMR during recovery and the higher the caloric requirement for weight gain.

5. It is suggested that the limit of oxygen uptake in recovery may be determined partly through the restoration of normal activity in the organs which are least reduced in relation to age and partly through the factor of the mean "metabolic potential" of the individual cell. Cell number per unit of tissue mass is increased in the active tissues of the malnourished growing animal. The mean respiratory activity per cell is therefore much reduced initially, but may approach the normal during recovery.

\section{REFERENCES}

1. Rubner, M., and Heubner, O. Die natürliche Ernährung eines Säuglings. Z. Biol. 1898, 36, 1.

2. Benedict, F. G., and Talbot, F. B. The gaseous metabolism of infants, with special reference to its relation to pulse-rate and muscular activity. Washington, D. C., Carnegie Institute, Publication 201, 1914.

3. Benedict, F. G., and Talbot, F. B. Metabolism and growth from birth to puberty. Washington, D. C., Carnegie Institute, Publication 302, 1921.

4. Levine, S. Z., and Wilson, J. R. The respiratory metabolism in infancy and in childhood. I. Basal metabolism of children. Amer. J. Dis. Child. 1926, 31, 323.

5. Karlberg, P. Determinations of standard energy metabolism (basal metabolism) in normal infants. Acta paediat. (Uppsala) 1952, 41, suppl. 89.

6. Talbot, F. B. Severe infantile malnutrition. The energy metabolism with the report of a new series of cases. Amer. J. Dis. Child. 1921, 22, 358.

7. Fleming, G. B., and Hutchison, H. S. A study of the metabolism in the undernourished infant. Quart. J. Med. 1924, 17, 339.
8. Wang, C. C., Kern, R., Frank, M., and Hays, B. B. Metabolism of undernourished children. II. Basal metabolism. Amer. J. Dis. Child. 1926, 32, 350.

9. Levine, S. Z., Wilson, J. R., and Gottschall, G. The respiratory metabolism in infancy and childhood. VIII. The respiratory exchange in marasmus : basal metabolism. Amer. J. Dis. Child. 1928, 35, 615.

10. Garot, L. Contribution à l'étude des troubles de métabolisme chimique dans la dénutrition grave du nourisson. Excrétion créatinique et métabolisme basal. Rev. franç. Pédiat. 1933, 9, 273.

11. Janet, H., and Bochet, M. Sur le métabolisme basal du nourisson. Bull. Soc. Pédiat. (Paris) 1933, 31, 359.

12. Kerpel-Fronius, E., Varga, F., Kun, K., and Vönöczky, J. Beitrag zur Klinik und pathologischen Physiologie der Säuglingsatrophie und Dekomposition. Acta. med. Acad. Sci. hung., 1951, 2, 59.

13. Karlberg, $P$. Methods of determining basal metabolism in relation to body measurements, blood volume, and heart volume in Infant Metabolism, I. H. Scheinberg, Ed. New York, Macmillan, 1956, p. 212.

14. Keys, A., Brozek, J., Henschel, A., Mickelson, O., and Taylor, H. L. The Biology of Human Starvation. Minneapolis, Minnesota Press, 1950, vol. 1, p. 303.

15. Talbot, F. B., Dalrymple, A. J., and Hendry, M. F. Skin temperature and basal metabolism during fasting. Amer. J. Dis. Child. 1925, 30, 491.

16. Varga, F. The respective effects of starvation and changed body composition on energy metabolism in malnourished infants. Pediatrics 1959, 23, 1085.

17. Waterlow, J. C., Ed. Protein Malnutrition. Proceedings of a Conference in Jamaica, 1953 (sponsored by the F.A.O., W.H.O. and Josiah Macy, Jr. Foundation). Cambridge, Univ. Press, 1955.

18. Kerpel-Fronius, E., and Kovach, S. The volume of extracellular body fluids in malnutrition. Pediatrics 1948, 2, 21.

19. Schnieden, H., Hendrickse, R. G., and Haigh, C. P. Studies in water metabolism in clinical and experimental malnutrition. Trans. roy. Soc. trop. Med. Hyg. 1958, 52, 169.

20. Smith, R. Total body water in malnourished infants. Clin. Sci. 1960, 19, 275.

21. Nelson, W. E., Ed. Textbook of Pediatrics, 6th ed. Philadelphia, Saunders, 1954, p. 54.

22. Waterlow, J. C. Fatty liver disease in infants in the British West Indies. Medical Research Council, Special Report no. 263. London, H. M. Stationery Office, 1948.

23. Jelliffe, D. B., Bras, G., and Stuart, K. L. Kwashiorkor and marasmus in Jamaican infants. W. Indian med. J. 1954, 3, 43.

24. Hansen, J. D. L. Protein malnutrtion and its prevention and treatment with special reference to kwashiorkor and marasmus in Recent Advances in Human Nutrition, J. F. Brock, Ed. London, Churchill, 1961, p. 267. 
25. Trowell, H. C. Non-infective Disease in Africa. London, Arnold, 1960, p. 334.

26. Bradley, J. E. S., Davidsson, D., MacIntyre, I., and Rapoport, A. Determination of total body water using tritium (Abstract). Biochem. J. 1956, 62, 34P.

27. Talbot, F. B. Standards of basal metabolism in normal infants and children. Amer. J. Dis. Child. 1921, 21, 519.

28. Waterlow, J. C. The rate of recovery of malnourished infants in relation to the protein and calorie levels of the diet. J. trop. Pediat. 1961, 7, 16.

29. Friis-Hansen, B. J., Holiday, M., Stapleton, T., and Wallace, W. M. Total body water in children. Pediatrics 1951, 7, 321.

30. Pace, N., and Rathbun, E. N. Studies on body composition. III. The body water and chemically combined nitrogen content in relation to fat content. J. biol. Chem. 1945, 158, 685.

31. Widdowson, E. M., McCance, R. A., and Spray, C. M. The chemical composition of the human body. Clin. Sci. 1951, 10, 113.

32. Shohl, A. T. Mineral Metabolism. New York, Reinhold, 1939, p. 19.

33. Steele, J. M., Brodie, D. B., Messinger, W. J., Soberman, R. J., Berger, E. Y., and Galdston, M. The relationship of body water to basal metabolic rate and surface area. Trans. Ass. Amer. Phycns 1949, 62, 214.

34. Addis, T., Poo, L. J., and Lew, W. Protein loss from liver during a two day fast. J. biol. Chem. 1936, $115,117$.

35. Kerpel-Fronius, E., and Frank, K. Einige Besonderheiten der Körperzusammensetzung und Wasserverteilung bei der Säuglingsatrophie. Ann. paediat. (Basel) 1949, 173, 321.
36. Widdowson, E. M., Dickerson, J. W. T., and McCance, R. A. Severe undernutrition in growing and adult animals. 4. The impact of severe undernutrition on the chemical composition of the soft tissues of the pig. Brit. J. Nutr. 1960, 14, 457.

37. Waterlow, J. C., Cravioto, J., and Stephen, J. M. L. Protein malnutrition in man. Advanc. Protein Chem. 1960, 15, 131.

38. Darrow, D. C., and Hellerstein, S. Interpretation of certain changes in body water and electrolytes. Physiol. Rev. 1958, 38, 114.

39. Mendes, C. B., and Waterlow, J. C. The effect of a low-protein diet, and of refeeding, on the composition of liver and muscle in the weanling rat. Brit. J. Nutr. 1958, 12, 74.

40. Kosterlitz, H. W. The effects of changes in dietary protein on the composition and structure of the liver cell. J. Physiol. (Lond.) 1947, 106, 194.

41. Waterlow, J. C., and Weisz, T. The fat, protein and nucleic acid content of the liver in malnourished human infants. J. clin. Invest. 1956, 35, 346.

42. Montgomery, R. D. Unpublished data.

43. Kety, S. S. Circulation and metabolism of the human brain in health and disease. Amer. J. Med. 1950, 8, 205.

44. Davies, M. On body size and tissue respiration. J. cell. comp. Physiol. 1961, 57, 135.

45. Kennedy, C., and Sokoloff, L. An adaptation of the nitrous oxide method to the study of the cerebral circulation in children; normal values for cerebral blood flow and cerebral metabolic rate in childhood. J. clin. Invest. 1957, 36, 1130.

46. Hogeboom, G. H., and Schneider, W. C. Sonic disintegration of isolated liver mitochondria. Nature (Lond.) 1950, 166, 302.

47. Gray, D. E., and Deluca, H. A. Use of desoxyribonucleic acid as a reference standard in metabolic experiments. Amer. J. Physiol. 1956, 184, 301. 